\title{
Neurotrophin-3 Antibodies Disrupt the Normal Development of the Chick Retina
}

\author{
Paola Bovolenta, ${ }^{1}$ José-María Frade, ${ }^{1}$ Elisa Martí, ${ }^{1}$ María-Angeles Rodríguez-Peña, ${ }^{2}$ Yves-Alain Barde,${ }^{3}$ and \\ Alfredo Rodríguez-Tébar ${ }^{1}$ \\ ${ }^{1}$ Cajal Institute, Consejo Superior de Investigaciones Cientificas, E-28002 Madrid, Spain, 2Instituto de Investigaciones \\ Biomédicas, E-28008 Madrid, Spain, and 3Max-Planck-Institute for Psychiatry, Department of Neurobiochemistry, 82152 \\ Planegg-Martinsried, Germany
}

\begin{abstract}
When chick embryos are treated with a monoclonal antibody specifically blocking the activity of neurotrophin-3 (NT-3), the development of the retina is profoundly affected. Fewer axons are found in the optic nerve, and the retina shows abnormalities in all layers. Early during retinogenesis, the proportion of dividing cells is higher in NT-3-deprived embryos compared with age-matched controls and that of differentiated neurons is smaller. The NT-3 receptor trkC is expressed early by a majority
\end{abstract}

The vertebrate retina is an interesting structure for studying how neuronal numbers and phenotypes are controlled during CNS development. Seven different cell types are generated within a short period of time, and cell lineage analyses indicate that the embryonic retina contains multipotent progenitor cells (Turner and Cepko, 1987; Holt et al., 1988). In addition, in vitro experiments with dissociated cells suggest that the retina generates intrinsic signals that contribute to the determination of cell fate and cell survival (Anchan et al., 1991; Althuser and Cepko, 1992; Watanabe and Raff, 1992; also see Kelley et al., 1994 and references therein). Hitherto, few such signals have been identified and shown to be physiologically relevant during normal development.

In this study, we examine the role of neurotrophin-3 (NT-3) in the development of the chick retina. Like other members of the neurotrophin gene family, NT-3 plays an essential role in the development of the nervous system. Deletion of the gene coding for NT-3 (Ernfors et al., 1994; Fariñas et al., 1994) or the NT-3 receptor trkC (Klein et al., 1994), or the administration of antibodies blocking the activity of NT-3 (Gaese et al., 1994), results in neuronal losses in peripheral ganglia. So far, however, there are no clear indications that NT-3, or indeed any other neurotrophins, also controls neuronal numbers in the CNS during normal development. Both NT-3 and trkC are expressed in many structures in the developing CNS (Tessarollo et al., 1993; Kahane and Kalcheim, 1994), and previous studies have demonstrated the presence of high-affinity NT-3 receptors on dissociated retinal cells as early as the fourth day of development (Rodríguez-Tébar et al.,

\footnotetext{
Received Nov. 13, 1995; revised April 25, 1996; accepted May 1, 1996.

This research was supported by Grants PB93-0124, DGICYT Ministry of Science, and SCI-551UE, Regional Government of Madrid and the Canary Islands. The expert comments of Carmen Prada on this manuscript and the retinal sections are gratefully acknowledged, as are early contributions from Karen Bailey and Andreas Hohn. Juan A. Maldonado and Rodrigo Rodríguez assisted with the electron microscopy.

Dr. Frade's present address: Max-Planck-Institute for Psychiatry, Department of Neurobiochemistry, 82152 Planegg-Martinsried, Germany.

Copyright (C) 1996 Society for Neuroscience $0270-6474 / 96 / 164402-09 \$ 05.00 / 0$
}

of retinal cells, and NT-3 is present in the retina at the earliest stage studied. Initially, it is located mainly in the pigmented epithelium, with a shift toward the neural retina as development proceeds. Thus, NT-3 seems to be an essential intrinsic signal acting early in development to promote the differentiation and survival of many retinal neurons.

Key words: retina; neuronal differentiation; retinal ganglion cells; cell number control; neurotrophin-3; chick embryo

1993). In addition, NT-3 also promotes in vitro the neuronal differentiation of thymidine-labeled precursor cells (De la Rosa et al., 1994). These results prompted us to test the role of NT-3 in vivo during chick retinal development, using a monoclonal antibody specifically blocking the biological activity of NT-3.

\section{MATERIALS AND METHODS}

\section{Antibodies}

The monoclonal antibodies 12 and 27/21 used here specifically block the biological activities of NT-3 and NGF, respectively (Gaese et al., 1994). Both belong to the mouse IgG1 subclass, and levels of $12-20 \mu \mathrm{g} / \mathrm{gm}$ wet weight were measured in the tectum of treated embryos using an enzyme immunoassay (Gaese et al., 1994). In the retina, the levels were $8.1 \pm 2.1$ $\mu \mathrm{g} / \mathrm{gm}$ at embryo day 6 (E6), $9.1 \pm 2.1 \mu \mathrm{g} / \mathrm{gm}$ at E9, and $10.5 \pm 5 \mu \mathrm{g} / \mathrm{gm}$ at E11. The monoclonal antibody G4 labels a glycoprotein located on neurites of a subset of differentiated neurons (Rathjen et al., 1987). It stains $10-12 \%$ of differentiated neurons in dissociated cultures from the E9 chick retina (data not shown), including the retinal ganglion cells and a population of neurons in the inner nuclear layer. The monoclonal antibody against chick Thy- 1 specifically recognizes retinal ganglion cells (Cohen et al., 1986; Sheppard, 1991).

\section{Chick embryos}

Fertilized eggs from White-Leghorn hens were obtained from a local supplier and incubated at $38.5^{\circ} \mathrm{C}$ in $70 \%$ humidity atmosphere, and the embryos were staged according to Hamburger and Hamilton (1951). Hybridoma cells secreting anti-NT-3 and anti-NGF antibodies were grown in ovo according to the procedure described previously for quail embryos (Rohrer et al., 1988). Eggs were incubated for 3 d (stages 14-15 of development), and a suspension of $2 \times 10^{6}$ hybridoma cells in $50 \mu \mathrm{l}$ PBS was applied onto the chorioallantois membrane.

\section{Cell culture}

Retinae from E8 or E9 embryos were dissected free from pigmented epithelium and dissociated as described previously (Rodríguez-Tébar et al., 1989). Briefly, retinae were placed in $1 \mathrm{ml} \mathrm{Ca}^{2+}, \mathrm{Mg}^{2+}$-free PBS containing $3 \mathrm{mg} / \mathrm{ml}$ bovine serum albumin and treated with $1 \mathrm{mg} / \mathrm{ml}$ trypsin (Worthington, Freehold, NJ) for $15 \mathrm{~min}$ at $37^{\circ} \mathrm{C}$. Digestion was stopped by adding $2 \mathrm{mg} / \mathrm{ml}$ soybean trypsin inhibitor (Sigma, St. Louis, MO). Cells were dissociated by passing 5-10 times through a wide-bore Pasteur pipette, suspended in culture medium, and plated onto $10 \mathrm{~mm}$ round glass coverslips in 4-well dishes (Greiner, Frickenhausen, Germa- 
Table 1. Optic nerve of control and anti-NT-3-treated embryos

\begin{tabular}{|c|c|c|c|c|c|c|}
\hline \multirow[b]{2}{*}{ Age } & \multicolumn{2}{|c|}{ Optic nerve mean area $\left(\mu \mathrm{M}^{2}\right)$} & \multicolumn{2}{|c|}{ Axonal density $\left(n / 1000 \mu \mathrm{M}^{2}\right)$} & \multicolumn{2}{|c|}{ Total number of axons } \\
\hline & Control $(n=3)$ & Anti-NT-3 $(n=5)$ & Control $(n=3)$ & Anti-NT-3 $(n=4)$ & Control $(n=2)$ & Anti-NT-3 $(n=5)$ \\
\hline E6 & $34,150 \pm 2741$ & $20,075^{*} \pm 5240$ & $9867 \pm 141$ & $8611^{* *} \pm 270$ & $336,761 \pm 23,806$ & $176,912 * \pm 50,112$ \\
\hline E9 & $141,667^{a} \pm 3786$ & $103,250^{* *} \pm 10,340$ & $20,240 \pm 4108$ & $11,014^{*} \pm 741$ & $2,840,556 \pm 553,058$ & $1,138,174 * * \pm 143,420$ \\
\hline E14 & $354,330 \pm 51,228$ & $161,800^{*} \pm 51,285$ & $7334 \pm 832$ & $5360 \pm 1435$ & $2,573,033 \pm 124,727$ & $910,310 * * \pm 446,000$ \\
\hline
\end{tabular}

${ }^{a}$ In three embryos treated with anti-NGF-secreting hybridoma cells, the mean optic nerve area was $142,665 \pm 6509 \mu \mathrm{M}^{2}$.

$* p<0.005 ; * p<0.001$.

ny). The coverslips were coated previously with polyornithine (Sigma) and laminin (Gibco, Paisley, Scotland), according to Collins (1978). The initial density of the cultures was between 48,700 and 54,100 cells $/ \mathrm{cm}^{2}$. Cells were cultured in 50\% DMEM/50\% F12 Ham (Sigma) with the N2 supplements described by Bottenstein and Sato (1979). The proportion of neurons was determined by tetanus toxin labeling (Mirsky et al., 1978). One hour after they were plated, the cells were fixed for $30 \mathrm{~min}$ with $4 \%$ paraformaldehyde and incubated for $30 \mathrm{~min}$ with $5 \mu \mathrm{g} / \mathrm{ml}$ of the tetanus toxin fragment $\mathrm{C}$ (Boehringer Mannheim, Mannheim, Germany); $1.5 \mathrm{U}$ of anti-tetanus toxin human immunoglobulin (Laboratorios Huber, Madrid, Spain) was then added and detection was performed with a Texas red-coupled anti-human antibody (Jackson ImmunoResearch Laboratories, West Grove, PA). Tetanus toxin-positive cells versus total cells were counted under fluorescence and phase-contrast microscopy. The proportion of proliferating cells was also determined. One hour after plating, the cells were fixed with methanol for $30 \mathrm{~min}$ at $-20^{\circ} \mathrm{C}$ and permeabilized with $0.5 \%$ NP-40 in PBS (Sigma) for $10 \mathrm{~min}$. The cells were then incubated for $30 \mathrm{~min}$ with $10 \mu \mathrm{g} / \mathrm{ml}$ anti-PCNA antibody (Boehringer Mannheim) in PBS, washed twice with PBS, and incubated for $30 \mathrm{~min}$ with a sheep anti-mouse IgG antibody (Amersham, Buckinghamshire, UK) diluted 1:100 in PBS. Proliferating cells were visualized by fluorescence microscopy after a 30 min incubation with streptavidin-Texas red (Amersham) (1:100 in PBS), and their proportion was determined by counting the total number of cells under phase-contrast microscopy.

\section{Northern blot analysis}

The pigmented epithelium was separated from the neuronal retina, and the RNA was extracted according to Chomczynski and Sacchi (1987). Ten micrograms of total RNA were separated on formaldehyde-containing gel (Lehrach et al., 1977), transferred to a nylon membrane, and hybridized with a ${ }^{32} \mathrm{P}$ cDNA probe $\left(2.3 \times 10^{9} \mathrm{cpm} / \mu \mathrm{g}\right)$ corresponding to the coding sequence of chick NT-3 (Maisonpierre et al., 1992). Hybridization was overnight at $65^{\circ} \mathrm{C}$ in $7 \% \mathrm{SDS}, 0.5 \mathrm{M}$ sodium phosphate buffer, $\mathrm{pH} 7.2$, containing $1 \mathrm{~mm}$ EDTA. After they were washed, the filters were exposed for autoradiography. The size of the single NT-3 transcript was $4.2 \mathrm{~kb}$.

\section{Histology}

Light microscopy. The embryos were killed, and their heads were fixed in $\mathrm{PBS} / 4 \%$ paraformaldehyde. After incubation for $2 \mathrm{~d}$ at $4^{\circ} \mathrm{C}$ in $100 \mathrm{~mm}$ sodium phosphate buffer, $\mathrm{pH} 7.3$, containing $30 \%$ sucrose, the tissue was embedded in OCT compound (Tissue-Tek; Miles, Elkhart, IN) and sectioned at $12-16 \mu \mathrm{m}$ using a cryostat. Sections were collected on gelatin-coated slides and stained with cresyl violet. For immunohistochemistry, sections were blocked with $100 \mathrm{~mm}$ glycine in PBS for $30 \mathrm{~min}$, followed by $1 \mathrm{hr}$ in PBS containing $0.1 \%$ Tween and $10 \%$ goat serum (PTG). Sections were then incubated overnight at $4^{\circ} \mathrm{C}$ with ascitis fluid diluted (in PTG) 1:250 (anti-Thy-1) and 1:250 (anti-G4). After they were rinsed twice in PBS/Tween, sections were incubated for $1 \mathrm{hr}$ with bioti-

\section{Table 2. Proportion of tetanus toxin- and PCNA-positive cells in control and anti-NT-3-treated E8 embryos}

\begin{tabular}{lll} 
& Tetanus toxin & PCNA \\
\hline Control $(n=3)$ & $30.6 \pm 2.9 \%$ & $77.3 \pm 5.3$ \\
Anti-NT-3 $(n=4)$ & $16.9 \pm 3.3 \%^{* *}$ & $90.1 \pm 3.9^{*}$ \\
\hline
\end{tabular}

One hour after plating ( $\sim 50,000$ cells $/ \mathrm{cm}^{2}$ from either control or treated embryos), cells were stained with the fragment $\mathrm{C}$ of tetanus toxin or with an antibody to PCNA. The proportion of stained cells was determined.

${ }^{*} p<0.01$ (Student's $t$ test); ${ }^{*} p<0.001$ (Student's $t$ test). nylated sheep anti-mouse IgG species-specific whole antibody (Amersham) diluted 1:300 in PBS/Tween, rinsed twice as above, and treated for $1 \mathrm{hr}$ with streptavidin-peroxidase (Jackson ImmunoResearch Laboratories) diluted 1:1000 in PBS/Tween and rinsed as above, followed by two PBS rinses. The antigen-antibody complex presence was then detected by incubation with $0.05 \%$ diaminobenzidine in the presence of $0.03 \% \mathrm{H}_{2} \mathrm{O}_{2}$, and the reaction was stopped by rinsing with water. For autoradiography of retinal sections, $12-100 \mu \mathrm{Ci}\left[{ }^{3} \mathrm{H}\right]$ thymidine was injected onto the chorioallantois membrane $24 \mathrm{hr}$ before the embryos were killed, and the embryos were fixed and sectioned as above. Retinal sections were washed in water, dehydrated in graded ethanol, dipped in NTB-2 emulsion (Eastman Kodak, Rochester, NY), and exposed for 10-25 d.

In situ hybridization. Hybridization on retinal sections was carried out according to Wilkinson and Nieto (1993). Briefly, embryos were fixed as above, tissues were dehydrated in graded ethanol and embedded in Paraplast (Sherwood Medical, St. Louis, MO), and 10-16 $\mu \mathrm{m}$ sections were mounted on $2 \% 3$-aminopropyltriethoxysilane-coated slides and dried at $37^{\circ} \mathrm{C}$ overnight. Slides were then dewaxed, rehydrated, postfixed, treated with proteinase $\mathrm{K}$ (Boehringer Mannheim) and $0.3 \%$ acetic anhydride, and incubated for $16 \mathrm{hr}$ at $60^{\circ} \mathrm{C}$ with radioactive probes used at $2 \times 10^{6} \mathrm{cpm}$ (see below). After two washes for $45 \mathrm{~min}$ with $50 \%$ formamide at $60^{\circ} \mathrm{C}$ and RNase treatment, the slides were autoradiographed using NTB-2 emulsion (Eastman Kodak) and a 2 week exposition time. ${ }^{35} \mathrm{~S}$-labeled probes were prepared and used as described by Wilkinson and Nieto (1993). The radioactive antisense cRNA probes and their corresponding sense controls were prepared by transcription of a cloned PCR fragment corresponding to bp 932-1449 of the chicken trkC cDNA sequence, comprising part of the extracellular and cytoplasmic domains of the protein; thus all known forms of trkC were recognized (Garner and Large, 1994).

Electron microscopy. Embryo heads were fixed in cacodylate buffer, $\mathrm{pH} 7.3$, containing $3 \%$ glutaraldehyde and $1 \%$ formaldehyde. The heads were washed in PBS, and the optic nerves were dissected out together with the optic fissure and processed for plastic embedding according to De Felipe and Fairén (1993). Briefly, optic nerves were treated "en bloc" with $100 \mathrm{~mm}$ sodium phosphate buffer, $\mathrm{pH}$ 7, containing $1 \%$ osmium tetroxide and $3 \%$ glucose for $40 \mathrm{~min}$, and repeatedly washed with PBS; the sections were dehydrated in graded ethanol followed by acetone. The tissue was immersed in acetone/Araldite (1:1) for $1 \mathrm{hr}$ at room temperature, infiltrated with pure Araldite overnight at $4^{\circ} \mathrm{C}$, flat-embedded in freshly prepared Araldite, and polymerized at $60^{\circ} \mathrm{C}$ for $2 \mathrm{~d}$. Semithin sections (1-3 $\mu \mathrm{m}$ thick) were collected on glass slides and routinely stained with a toluidine blue solution. Finally, ultrathin sections (1-3 nm thick) were stained with uranyl acetate and lead citrate and examined in a Jeol 1200 EX electron microscope at a magnification of $30,000 \times$. Nerve cross-sections were obtained from the region midway between the optic stalk and the entrance in the cranial cavity. The total number of optic nerve fibers at three developmental stages was calculated by multiplying the cross-sectional area of the sections by the mean fiber density (Rager, 1980). The cross-sectional area was measured on semithin sections with the aid of an Argus-10 Image Processor System coupled to a Diaphot inverted microscope (Nikon). Approximately 50 micrographs were taken for each sample at the same magnification of $30,000 \times$. The number of axonal or growth cone profiles present in each micrograph was determined, and the mean density was calculated.

\section{RESULTS}

\section{Retinal NT-3 and trkC}

Northern blot analyses revealed that at E5, NT-3 mRNA is expressed predominantly in the pigmented epithelium with 

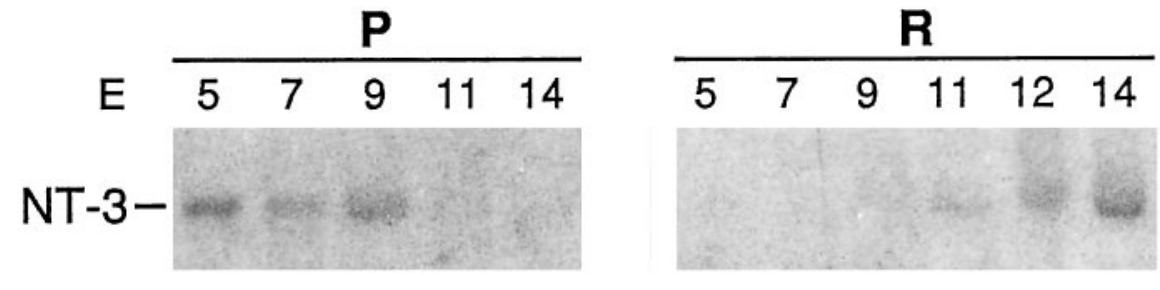

Figure 1. Northern blot analysis of NT-3 expression during retinal development. Total RNA as extracted at the indicated embryonic ages $(E)$ from either the pigmented epithelium $(P)$ or the neural retina $(R)$ and gel-fractionated. The blots were hybridized with ${ }^{32}$ P-labeled chick NT-3 cDNA probe (top). Bottom, Methylene-blue staining of the ribosomal RNA of the blots.
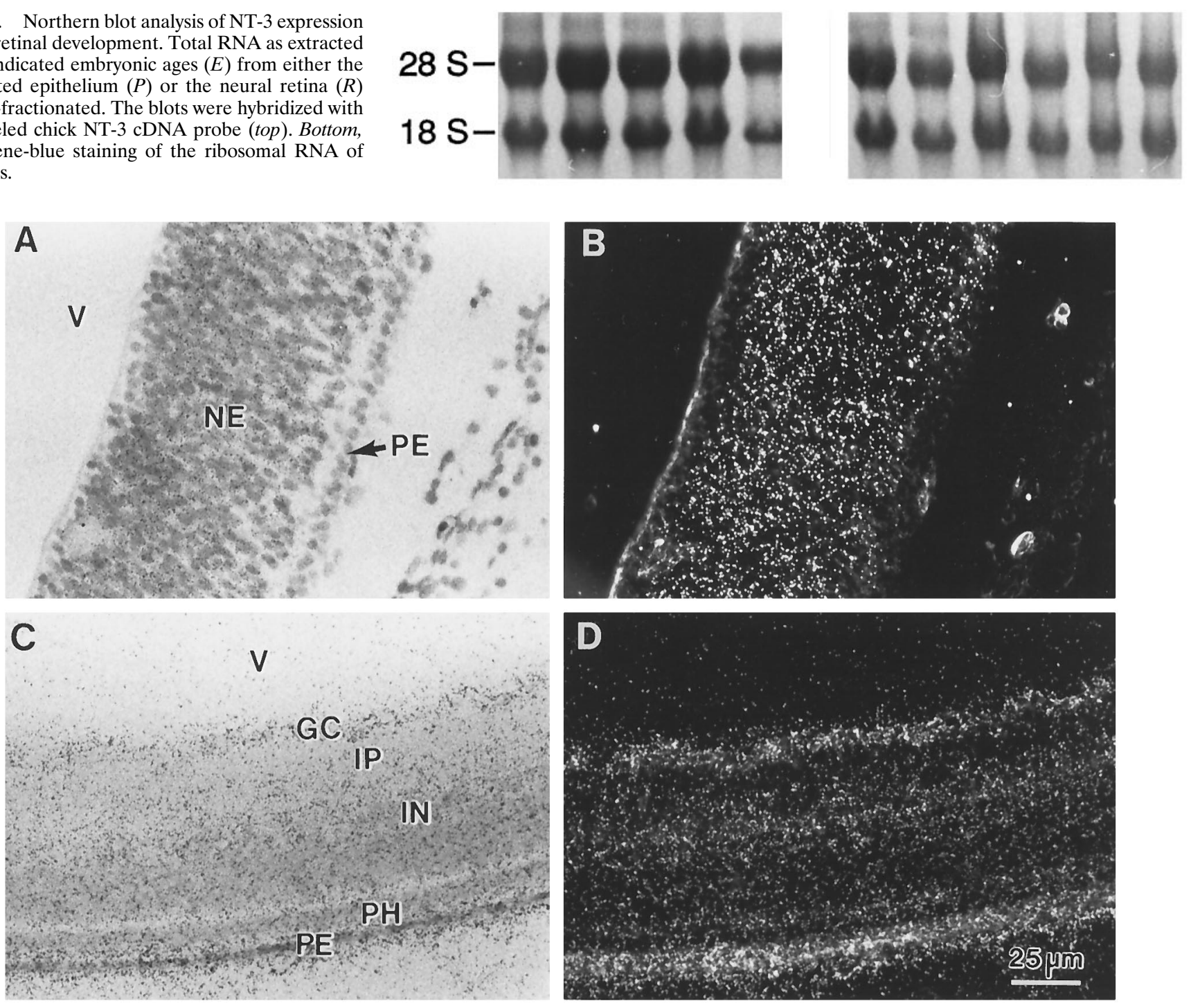

Figure 2. TrkC expression during retinal development. E5 $(A, B)$ and $\mathrm{E} 12(C, D)$ retinae were hybridized with an antisense trkC cRNA probe. Note that at E5 most cells express trkC, whereas at E12 higher expression levels are seen over the inner part of the inner nuclear layer and the retinal ganglion cell layer. $A, C$, Bright-field pictures of the retina; $B, D$, dark-field pictures of the retina. In $D$, the signal in the pigmented epithelium is attributable to the pigment granules. Unlike the rest of the expression pattern described here, it is also seen with the trkC sense probe. $N E$, Neuroepithelium; $P E$, pigmented epithelium; $V$, vitreous body; $G C$, ganglion cell layer; $I P$, inner plexiform layer; $I N$, inner nuclear layer; $P H$, photoreceptor layer.

very low levels in the neural retina. As development proceeds, NT-3 mRNA levels increase progressively in the neural retina and decrease in the pigmented epithelium (Fig. 1). Because a previous study has indicated the presence of high-affinity receptors for NT-3 on dissociated retinal cells (Rodríguez-Tébar et al., 1993), we were interested in determining the cellular site of expression of trkC, a specific receptor for NT-3 (Lamballe et al., 1991). In situ hybridization experiments were performed using retinae of various embryonic ages. We found that trkC mRNA is expressed by most cells in the E5 retina, at a time when the vast majority of the cells is still undifferentiated (Fig. $2 A, B)$. At E12, trkC expression is found in all nucleated layers, with higher expression levels in the ganglion cell layer and in the inner part of the inner nuclear layer (Fig. 2C,D). 

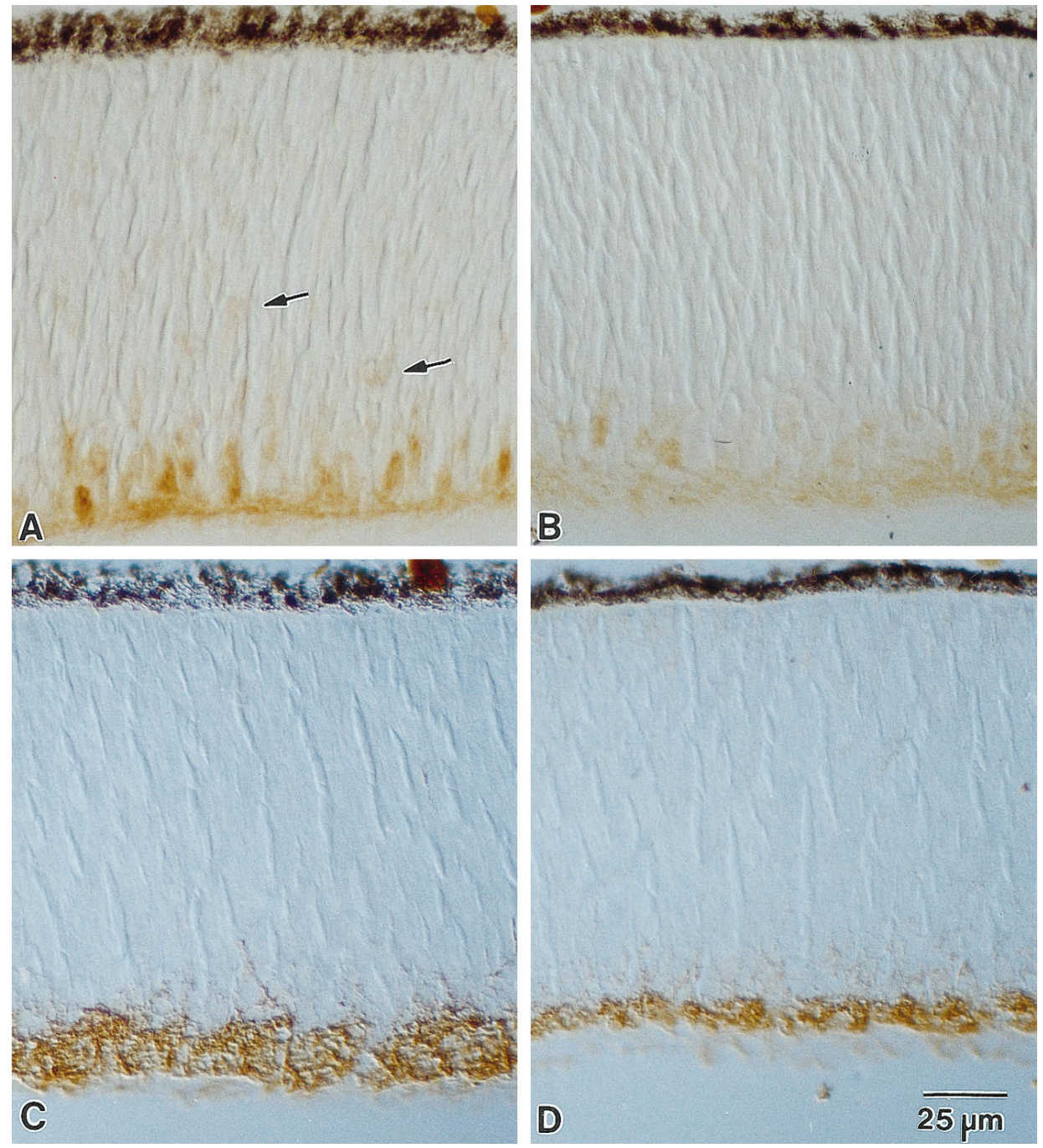

Figure 3. NT-3 deprivation interferes with the differentiation of the retinal ganglion cells. $A, C$, Control embryos; $B, D$, anti-NT-3treated embryos. E6 retinae were stained with a monoclonal antibody to Thy-1 $(A, B)$ or $\mathrm{G} 4$ $(C, D)$. The top dark lines correspond to the pigmented epithelium. Note that the Thy-1 antibody also stains migrating ganglion cells (arrows in $A$ ), which are absent in the retina from treated animals $(B)$. At this stage, the $\mathrm{G} 4$ antibody stains primarily the differentiated ganglion cells $(C)$, which are reduced in numbers in treated animals $(D)$.

\section{Embryo treatment with anti-NT-3 antibodies}

To test whether retinal development is altered in the absence of NT-3, we used hybridoma cells secreting an antibody specifically blocking its biological activity. Starting at E3, the cells were grown onto the chorioallantois membrane, and the embryos were killed at E6, E9, and E14. In control experiments, hybridoma cells secreting an NGF-antibody were used. Although neither the retina nor the optic nerve of anti-NGF-treated embryos revealed obvious differences compared with control embryos, those from anti-NT-3-treated animals exhibited marked morphological alterations at all ages examined.

\section{E6}

A normal E6 retina consists of a broad pseudostratified proliferating layer, composed mostly of undifferentiated cells, and an incomplete ganglion cell layer; only $60 \%$ of these cells are postmitotic at this age in the central retina (Prada et al., 1991). The retinae of control and treated animals were compared using an antibody to Thy-1, which labels the cell bodies and the axons of the retinal ganglion cells (Cohen et al., 1986; Sheppard et al., 1991) as well as scattered cells within the retina that correspond to immature ganglion cells born at the ventricular region and migrating toward their final destination at the vitreal surface of the retina (Fig. 3A, arrows) (see Prada et al., 1981). These migrating cells (which have also been described in the rat retina; McLoon and Barnes, 1989) were found in much reduced numbers in retinae from anti-NT-3-treated embryos (Fig. 3B), indicating decreased numbers of retinal ganglion cells. This was confirmed by the staining pattern obtained with the G4 antibody (Rathjen et al., 1987). At this age, the antibody stains only the fibers of differentiated ganglion cells, and comparisons between treated and control embryos revealed a lower staining density, presumably as a result of the lower number of differentiated retinal ganglion cells (Fig. $3 C, D$ ). To determine their numbers in both treated and control retinae, ganglion cell axons were counted in the optic nerve (Table 1). In treated embryos, the number was only $\sim 51 \%$ of the controls, in which axonal number, cross-sectional areas, and fiber density values were essentially as those reported by Rager (1980). Taken together, these results indicate that NT-3 deprivation interferes markedly with the development of retinal ganglion cells. It is unclear, however, whether the NT-3 deprivation merely delays the development of the retina and the ganglion cells (at this early age, the axon number doubles every $12 \mathrm{hr}$; Rager, 1980) or whether many ganglion cells are absent because they fail to differentiate. Retinae from older embryos were examined to clarify this point.

\section{E8-9}

Staining the retina with cresyl violet revealed numerous differences when control retinae were compared with those from anti- 


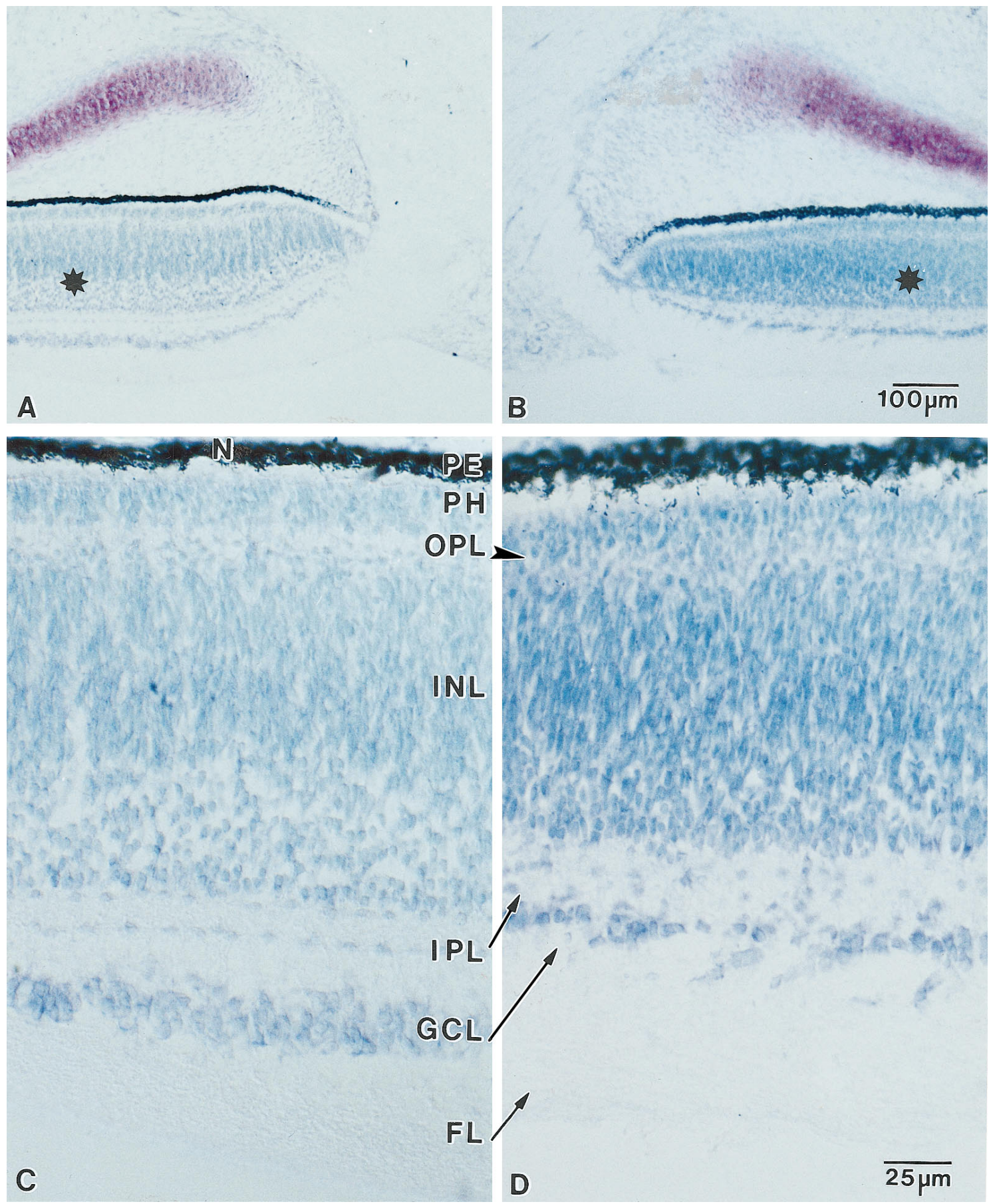

Figure 4. NT-3 deprivation affects retinal development at E9. Sections of control $(A, C)$ and anti-NT-3-treated embryos $(B, D)$ were stained with cresyl violet. Note the reduction in the overall thickness of the retina (for further description, see Results). $C$ and $D$ are higher magnifications of the areas indicated in $A$ and $B$ by asterisks. $N$, Normal retina; $P E$, pigmented epithelium; $P H$, photoreceptor layer; $O P L$, outer plexiform layer; $I N L$, inner nuclear layer; $I P L$, inner plexiform layer; $G C L$, ganglion cell layer; $F L$, fiber layer.

NT-3-treated animals (Fig. 4). The latter were consistently thinner, the outer plexiform layer was hardly delineated, and the layer of photoreceptor neuroblasts did not form the usual ordered array. In addition, the inner plexiform was also thinner, and the migrating inverted (displaced) amacrine neurons were fewer and did not form the typical advancing row as seen in the controls (Fig. 4). The inner nuclear layer seemed to be constituted mostly of tightly compacted neuroepithelial cells, whereas in control embryos, the inner third of this layer was apparently formed by loosely dispersed, probably amacrine cells (Fig. 4). The proportion of differentiated and dividing retinal cells in control and anti-NT-3-treated embryos was then quantified. Retinae were dissociated, plated for $1 \mathrm{hr}$ to allow attachment, and stained with either tetanus toxin or PCNA antibodies (Table 2). The antibody treatment produced a substantial reduction $(39 \%)$ of the proportion of differentiated neurons, compared with age-matched controls, and a $13 \%$ increase of PCNA-positive cells. Evidence for a larger proportion of dividing cells in antibody-treated animals was 


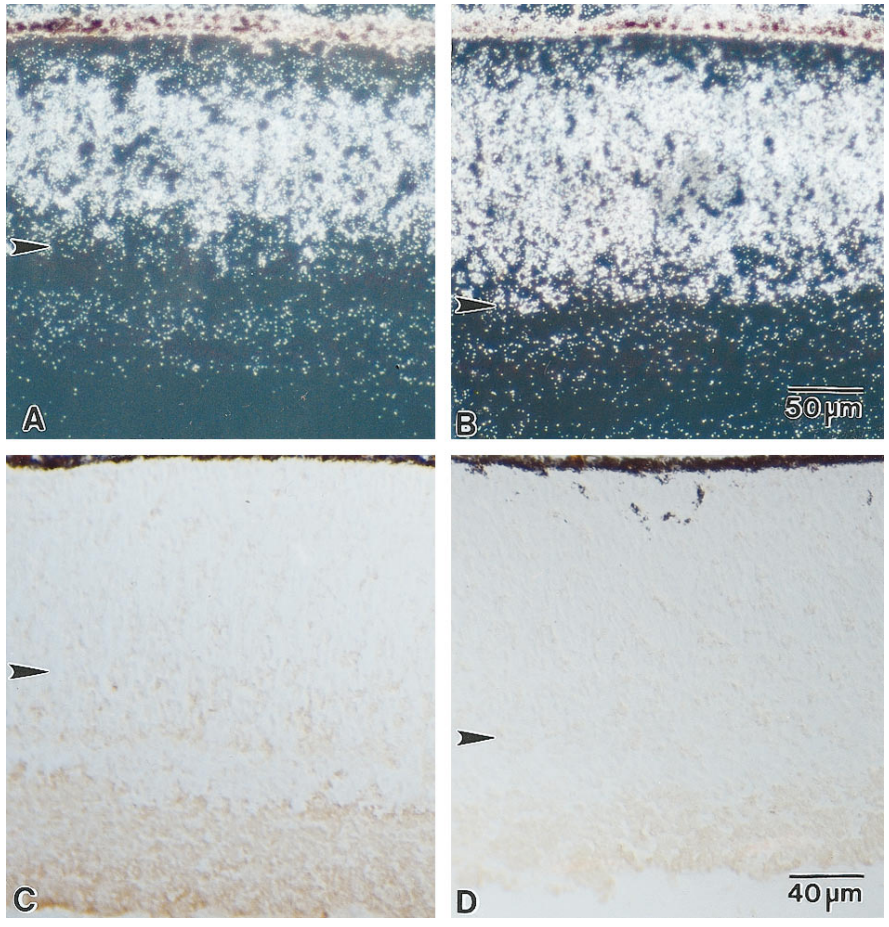

Figure 5. $\left[{ }^{3} \mathrm{H}\right]$ thymidine incorporation is increased in anti-NT-3-treated animals. E8 embryos were injected with $100 \mu \mathrm{Ci}$ thymidine $24 \mathrm{hr}$ before they were killed, and similar retinal areas were analyzed in control and antibody-treated animals. Note that in the control retina $(A)$, the inner third of the inner plexiform layer shows no thymidine incorporation (compare arrowhead in $A$ with arrowhead in $B$; anti-NT-3-treated). In $C$ (control) and $D$ (treated), the sections were stained with the G4 antibody, a marker for differentiated, thymidine-negative neurons.

also obtained in vivo. $\left[{ }^{3} \mathrm{H}\right]$ thymidine was injected $24 \mathrm{hr}$ before the embryos were killed, and retinal sections were processed for autoradiography at E9. Figure 5, $A$ and $B$, shows that in treated embryos, thymidine labeling spreads across the entire thickness of the inner nuclear layer, reaching the boundary with the inner plexiform layer. Thus, most cells in the inner nuclear layer were still in mitosis in anti-NT-3-treated embryos. By contrast, in control embryos, labeling was confined to the outer two thirds of the inner nuclear layer, with no thymidine signal being detected over the inner third of the inner nuclear layer. These results suggest that undifferentiated cells, when deprived of NT-3, retain their capacity to proliferate for longer than normal. The postmitotic cells present in the control, but not in the anti-NT-3-treated embryos, were differentiated neurons, as indicated by staining of adjacent sections with the G4 antibody (compare Fig. $5 C$ with $D$ ). In anti-NT-3-treated embryos, the retinal ganglion cell layer was clearly thinner and less densely populated, and a marked reduction $(60 \%$, Table 1$)$ in the number of ganglion cells was demonstrated by counting axonal numbers. In anti-NGF-treated embryos, no changes were observed in the optic nerve mean area (Table 1). In anti-NT-3-treated embryos, axonal bundles were smaller and contained more growth cone profiles, as compared with corresponding controls (data not shown), indicating that the differentiation of the retinal ganglion cells is retarded in treated embryos.

\section{E14}

Because the final, basic configuration of the retina is essentially reached at E14 (Rager, 1980), it was of interest to compare sections from treated and control embryos at this age (Fig. 6). In treated embryos, the final stratification of the retina was not achieved, as revealed in particular by the lack of a clearly identifiable outer plexiform layer (thick arrow in Fig. $6 \mathrm{~A}$; compare with $6 B$ ) and the failure of the photoreceptor inner segment to develop with straight cell bodies and nuclei close to the outer plexiform layer, as described in Morris and Shorey (1967) and Ramón y Cajal (1992) (data not shown). In addition, the inner plexiform layer was slender and devoid of its characteristic structure: the two parallel dark lines described by Coulombre (1955) (Fig. 6A, thin arrows). In normal embryos, the inner line appears at E9 and is formed by the synapses between the bipolar cells and the ganglion cells, whereas the outer line appears at E10 and is formed by the synapses between ganglion cells and amacrine cells. Thus, the lack of these two lines in the treated embryos is a sign of substantial disorganization of the synapses normally formed by the retinal ganglion cells and the amacrine and bipolar cells. In cresyl violetstained sections, the number of ganglion cells also seemed to be decreased greatly in the retinas of treated embryos (Fig. 6B).

The cross-sectional areas of anti-NT-3-treated nerves were much smaller than those of untreated, control embryos (Fig. 7A, $C$, Table 1), whereas the fiber density was reduced moderately. As a consequence, the total axon number decreased to $\sim 33 \%$ of that of control nerves (Table 1). In general, anti-NT-3-treated nerves contained small bundles of axons composed of fewer fibers than those of control embryos (Fig. 7B,D). Unlike at E9, growth cone profiles were not detected, indicating that differentiation of ganglion cells did not proceed any longer in embryos treated with anti-NT-3 antibodies.

\section{DISCUSSION}

The main result of this study is that NT-3 is required for the normal development of a CNS structure, the chick retina. When endogenous NT-3 is neutralized, the retina is reduced in size and abnormal in its organization. NT-3 is needed early, when most retinal neurons are still being generated. Thymidine-labeling and PCNA-staining experiments indicate that in the absence of NT-3, a higher proportion of proliferating cells is observed compared with age-matched controls.

\section{NT-3 influences early retinal development}

At E6, fewer retinal ganglion cells are seen in the retina of anti-NT-3-treated embryos, and fewer axons are counted in the optic nerve. Clearly, this cannot be a consequence of a reduced amount of tectal-derived NT-3, because only a very small proportion of retinal ganglion cell axons have reached the tectum. Thus, mechanisms other than the classical target-derived control of neuronal numbers must be envisaged. The analysis of the retina at E6 with Thy-1 antibodies indicates that in anti-NT-3-treated embryos, fewer retinal ganglion cells are seen migrating on their way to their final destination, the ganglion cell layer. It thus seems that NT-3 might be an essential factor promoting the differentiation and/or survival of these cells. This is consistent with the results of a previous study using cells isolated from the chick retina at E5: three times as many cells are G4- and thymidine-positive when cultured with NT-3 (but not with BDNF) (De la Rosa et al., 1994). These effects are seen at low concentrations of NT-3 $(2 \mathrm{ng} / \mathrm{ml})$, and previous binding studies have demonstrated the presence of specific, high-affinity NT-3 receptors on such cells at E4 (Rodríguez-Tébar et al., 1993). Taken together, these data suggest that NT-3 is a necessary signal acting on trkC-expressing retinal cells when they still divide. A likely source of NT-3 at early stages is the pigmented epithelium, because it is only after E9 that 
substantial quantities of NT-3 mRNA can be detected in the neural retina (Fig. 1) (Hallböök et al., 1996). As predicted for a differentiation-promoting role of NT-3, thymidine incorporation is increased in antibody-treated embryos, and in vitro experiments indicate a significant increase in the proportion of PCNA-positive cells when compared with controls. It thus seems that a major consequence of NT-3 deprivation is a failure of many retinal cells to come out of the cell cycle at the appropriate time. Although this should lead to the generation of more cells, no evidence was found for increased cell numbers. Presumably, the extra cells that are generated die rapidly by programmed cell death for lack of the necessary survival factors, including NT-3 (see below).

\section{NT-3 as a survival factor for differentiated retinal neurons}

Two consecutive waves of high-affinity NT-3 receptors have been noted during retinal development, peaking at E7 and E12 (Rodríguez-Tébar et al., 1993). TrkC mRNA is already present throughout the retina at E5 and in the three nucleated layers at E12 (Fig. 2C,D) (Hallböök et al., 1996). Presumably, the second wave of high-affinity NT-3 receptors reflects the survival function of NT-3 for some differentiated neurons, and previous cell culture experiments with retinae dissociated at E9 and E11 have indicated that NT-3 prevents the death of a subset of amacrine and ganglion cells (De la Rosa et al., 1994).

E14 retinae present a complex pattern of alterations, and large numbers of ganglion cells ( $\sim 70 \%$ as deduced from axonal counts) are missing. The marked reduction in axonal number is likely attributable to the smaller number of retinal ganglion cells generated and surviving until this stage in the absence of NT-3; in addition, it also might be secondary to the loss of other cell types in the retina or of oligodendrocytes in the optic nerve. Indeed, in the rat optic nerve, NT-3 deprivation experiments induced a $50 \%$ reduction in the number of oligodendrocytes in the optic nerve (Barres et al., 1994). In the retinae of treated embryos, the inner plexiform layer was narrower at E14, most likely as a result of the reduced neuronal number in the adjacent layers. These E14 retinae also lack the typical organized structure resulting from the alignments of the synaptic contacts between the ganglion cells with amacrine and bipolar cells. The dendritic arborization of the retinal ganglion cells might also be affected as a result of NT-3 deprivation. The outer plexiform layer is also ill-defined, presumably as a result of a defect in the establishment of a normal connectivity between photoreceptor and bipolar cells.

In sum, it seems that NT-3 either directly or indirectly influences the development and connectivity of most cell types in the retina and that these effects are not transient but are increasingly dramatic as the retina develops in an organized, layered structure.

\section{Control of cell numbers by NT-3 during nervous system development}

Targeted mutations have been introduced in the NT-3 and trkC genes, and severe morphological alterations have been observed in the PNS (Ernfors et al., 1994; Fariñas et al., 1994; Klein et al., 1994). Two reports indicate that neuronal losses occur early in development, suggesting an early role for NT-3 during neurogenesis (Gaese et al., 1994; Tessarollo et al., 1994), and a recent analysis indicates that NT-3 is a necessary survival factor for dividing sensory neuroblasts (ElShamy and Ernfors, in press). In addition, recent in vivo data also indicate that NT-3 acts as an anti-proliferative factor during sensory gangliogenesis: the application of NT-3 early in development markedly decreases the size of sensory ganglia and the number of proliferating cells (Ockel et al., 1996). The results of the present study indicate similar roles for NT-3 during retinogenesis, namely those of an essential survival and differentiation, anti-proliferative signal.

Hitherto, there are no convincing demonstrations that any of the neurotrophins regulate neuronal numbers during normal CNS development. Gene knock-out studies have not been informative in this respect, and although it is unclear whether the developing retina has been studied extensively in NT-3 or trkC knock-out animals, it is unlikely that changes of the magnitude of those reported here would not have been noted. In two NT-3 knock-out studies, however, it has been noted that the spinal cord of these animals is smaller than in the control (Fariñas et al., 1994; Tessarollo et al., 1994), but the reasons for this size reduction are unclear and have not been analyzed. Possibly, compensatory mechanisms cannot operate efficiently in the developing chick retina when an acute NT-3 deprivation is imposed during the time when very large numbers of cells are generated rapidly. Other

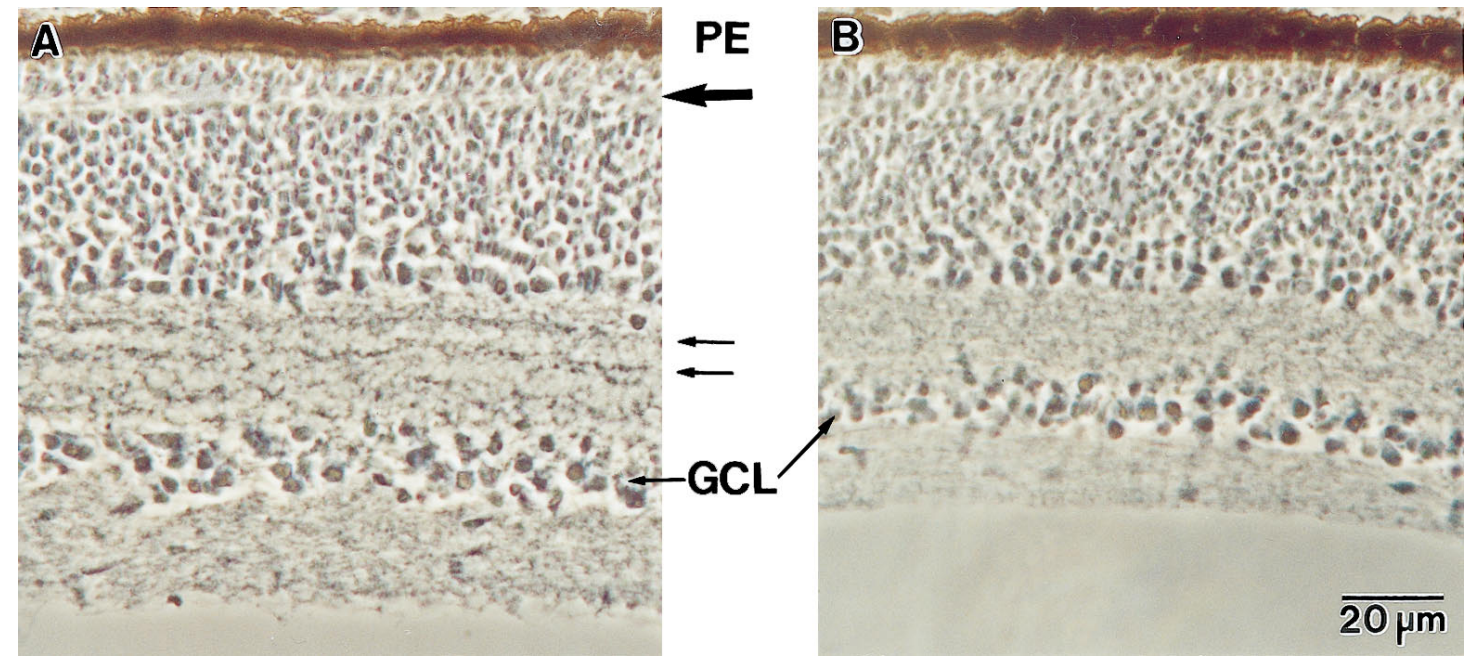

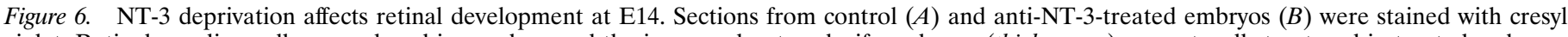

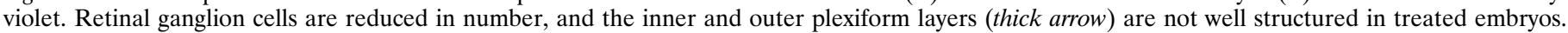

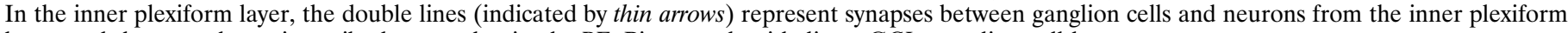
layer, and they are absent in antibody-treated animals. PE, Pigmented epithelium; $G C L$, ganglion cell layer. 

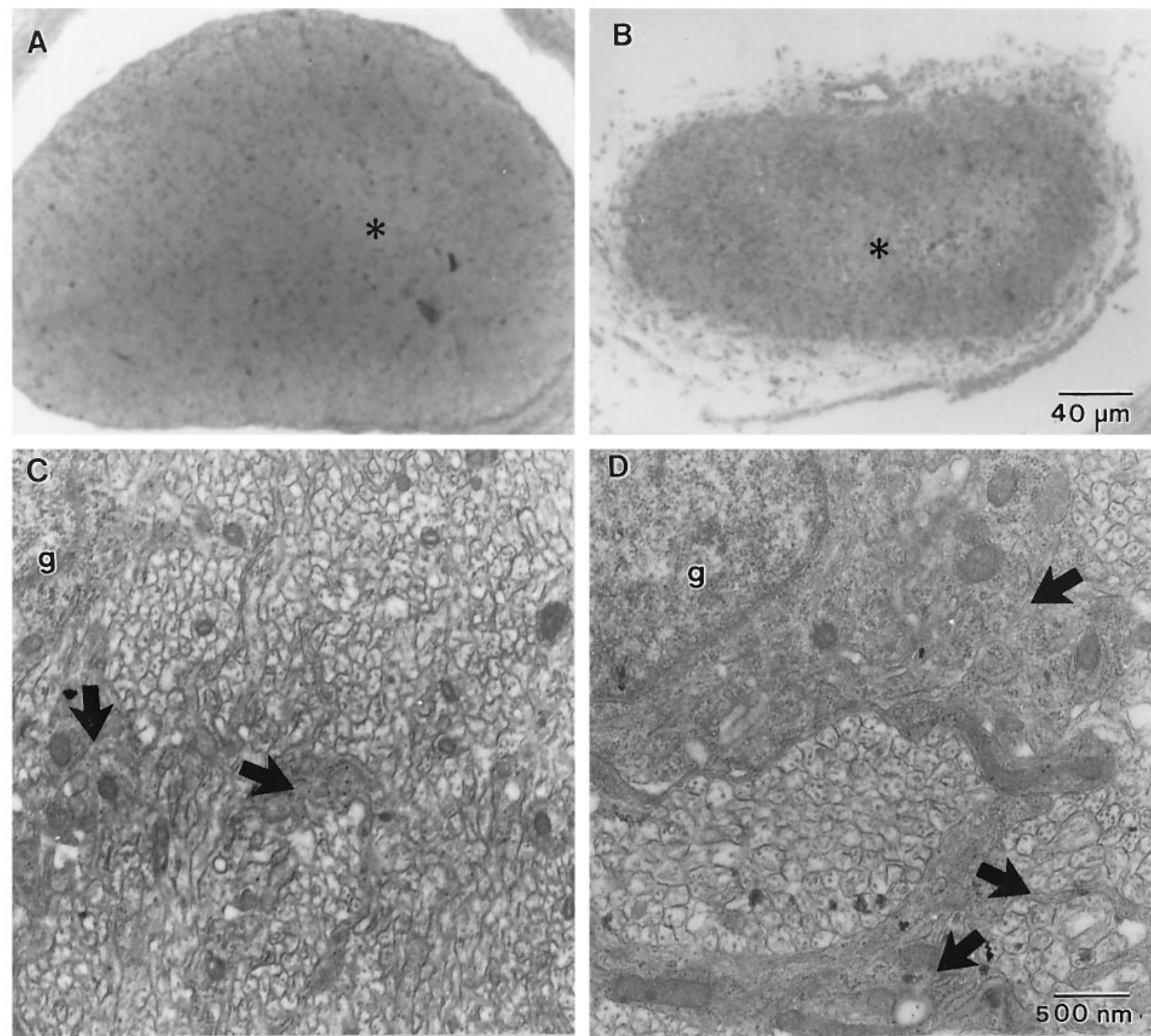

Figure 7. Sections of optic nerves from control $(A, C)$ and anti-NT-3-treated $(B, D)$ embryos. $A$ and $B$ are low-power sections from whole nerves at E14, and the asterisks indicate the position at which the corresponding electron micrographs were taken $(C, D)$. Note that in treated embryos, more glial cell profiles (thick arrows) can be observed in the nerves that contain fewer axons organized in smaller bundles. $g$, Glial cell nucleus.

differences between chick and mouse retinal cells can be envisaged, one being that NT-3 does not play the same role in mouse and chick retinogenesis.

In conclusion, this study indicates that in the absence of NT-3, the development of the chick retina is grossly abnormal and includes a large decrease in neuronal numbers. The results also indicate that NT-3 acts early during neurogenesis to control cell proliferation and survival.

\section{REFERENCES}

Altshuler D, Cepko C (1992) A temporally regulated, diffusible activity is required for rod photoreceptor development in vitro. Development 114:947-957.

Anchan RM, Reh TA, Angello J, Balliet A, Walker M (1991) EGF and TGF- $\alpha$ stimulate retinal neuroepithelial cell proliferation in vitro. Neuron 6:923-936.

Barres BA, Raff MC, Gaese F, Bartke I, Dechant,G, Barde Y-A (1994) A crucial role for neurotrophin-3 in oligodendrocyte development. Nature 367:371-375.
Bottenstein J, Sato GH (1979) Growth of a rat neuroblastoma cell line in a serum-free supplemented medium. Proc Natl Acad Sci USA 76:514-517.

Chomczynski P, Sacchi N (1987) Single-step method of RNA isolation by acid guanidinium thiocyanate-phenol-chloroform extraction. Anal Biochem 162:156-159.

Cohen J, Burne JF, Winter J, Bartlett P (1986) Retinal ganglion cells lose response to laminin with maturation. Nature 322:465-467.

Collins F (1978) Axon initiation by ciliary neurons in culture. Dev Biol 65:50-57.

Coulombre AJ (1955) Correlation of structural and biochemical changes in the developing retina of the chick. Am J Anat 96:153-189.

De Felipe J, Fairén A (1993) A simple method for correlative light and electron microscopic studies. J Histochem Cytochem 41:769-772.

De la Rosa E, Arribas A, Frade JM, Rodríguez-Tébar A (1994) Role of neurotrophins in the control of neural development: neurotrophin-3 promotes both neuron differentiation and survival of cultured retinal cells. Neuroscience 58:347-352.

ElShamy WM, Ernfors P (1996) An autocrine/paracrine NT-3 loop prevents the cell death of proliferating sensory precursor neurons. Neuron, in press. 
Ernfors P, Lee K-F, Kucera J, Jaenisch R (1994) Lack of neurotrophin-3 leads to deficiencies in the peripheral nervous system and limb proprioception. Cell 77:503-512.

Fariñas I, Jones KR, Backus C, Wang X-Y, Reichardt LF (1994) Severe sensory and sympathetic deficits in mice lacking neurotrophin-3. Nature 369:658-661.

Gaese F, Kolbeck R, Barde Y-A (1994) Sensory ganglia require neurotrophin-3 early in development. Development 120:1613-1619.

Garner AS, Large TH (1994) Isoforms of the avian TrkC receptor: a novel kinase insertion dissociates transformation and process outgrowth from survival. Neuron 13:457-472.

Hallböök F, Bäckström A, Kullander K, Ebendal T, Carri NG (1996) Expression of neurotrophins and their receptors in the avian retina. J Comp Neurol 364:664-676.

Hamburger V, Hamilton H (1951) A series of normal stages in the development of chick embryo. J Morphol 88:49-92.

Holt CE, Bertsch TW, Ellis HM, Harris WA (1988) Cellular determination in the Xenopus retina is independent of lineage and birth date. Neuron 1:15-26.

Kahane N, Kalcheim C (1994) Expression of trkC receptors mRNA during development of the avian nervous system. J Neurobiol 25:571-584.

Kelley MW, Turner JK, Reh TA (1994) Retinoic acid promotes differentiation of photoreceptors in vitro. Development 120:2091-2102.

Klein R, Silos-Santiago I, Smeyne RJ, Lira S, Brambrilla R, Bryant S, Zangh L, Snider WD, Barbacid M (1994) Disruption of the neurotrophin-3 receptor gene trkC eliminates Ia muscle afferents and results in abnormal movements. Nature 368:249-251.

Lamballe F, Klein R, Barbacid M (1991) trkC, a new member of the trk family of tyrosine protein kinases, is a receptor for neurotrophin-3. Cell 66:967-979.

Lehrach H, Diamond D, Wozney JM, Boedtker H (1977) RNA molecular weight determinations by gel electrophoresis under denaturing conditions, a critical re-examination. Biochemistry 16:4743-4751.

Maisonpierre PC, Belluscio L, Conover JC, Yancopoulos GD (1992) Gene sequences of chicken BDNF and NT-3. DNA Seq 3:49-54.

McLoon SC, Barnes RB (1989) Early differentiation of retinal ganglion cells: an axonal protein expressed by premigratory and migrating retinal ganglion cells. J Neurosci 9:1424-1432.

Mirsky R, Wendon LM, Black P, Stolkin C, Bray D (1978) Tetanus toxin: a cell surface marker for neurones in culture. Brain Res 148:251-259.

Morris VB, Shorey CD (1967) An electron microscopic studies of types of receptor in the chick retina. J Comp Neurol 129:313-339.
Ockel M, Lewin GR, Barde Y-A (1996) In vivo effects of neurotrophin-3 during sensory neurogenesis. Development 122:301-307.

Prada C, Puelles L, Genis-Gálvez JM (1981) A Golgi study on the early sequence of differentiation of ganglion cells in the chick embryo retina. Anat Embryol 161:305-317.

Prada C, Puga J, López-Méndez L, López R, Ramírez G (1991) Spatial and temporal patterns of neurogenesis in the chick retina. Eur $\mathrm{J}$ Neurosci 3:559-569.

Rager G (1980) Development of the retino-tectal projection in the chicken retina. Adv Anat Embryol Cell Biol 63:1-92.

Ramón y Cajal S (1992) The structure of the retina. Springfield, IL: Charles C Thomas.

Rathjen FG, Wolf JM, Franck R, Bonhoeffer F, Rutishauser U (1987) Membrane glycoproteins involved in neurite fasciculation. J Cell Biol 104:343-353.

Rodríguez-Tébar A, De la Rosa E, Arribas A (1993) Neurotrophin-3 receptors in the developing chicken retina. Eur J Biochem 211:789-794.

Rodríguez-Tébar A, Jeffrey PL, Thoenen H, Barde Y-A (1989) The survival of chick retinal ganglion cells in response to brain-derived neurotrophic factor depends on their embryonic age. Dev Biol 136:296-303.

Rohrer H, Hofer M, Hellweg R, Korsching S, Stehle AD, Saadat S, Thoenen H (1988) Antibodies against nerve growth factor interfere in vivo with the development of avian sensory and sympathetic neurons. Development 103:545-552.

Sheppard AM, Konopka M, Robinson SR, Morgan IG, Jeffrey PL (1991) Thy-1 antigen is specific to ganglion cells in chicks. Neurosci Lett 123:87-90.

Tessarollo L, Tsoulfas P, Martin-Zanca D, Gilbert DJ, Jenkins NA, Copeland NG, Parada LF (1993) trkC, a receptor for neurotrophin-3, is widely expressed in the developing embryo and in non-neuronal tissues. Development 118:463-475.

Tessarollo L, Vogel KS, Palko ME, Reid SW, Parada LF (1994) Targeted mutation in the neurotrophin-3 gene results in loss of muscle sensory neurons. Proc Natl Acad Sci USA 91:11844-11848.

Turner DL, Cepko CL (1987) A common progenitor for neurons and glia persists in rat retina late in development. Nature 328:131-136.

Watanabe T, Raff MC (1992) Diffusible rod-promoting signals in the developing rat retina. Development 114:899-906.

Wilkinson DG, Nieto MA (1993) Detection of messenger RNA by in situ hybridisation to tissue sections and whole mounts. Methods Enzymol 225:361-373. 